\title{
Tylophorine Abrogates G2/M Arrest Induced by Doxorubicine and Promotes Increased Apoptosis in T47D Breast Cancer Cells
}

\author{
Nofran Putra Pratama1, Septi Wulandari', Agung Endro Nugroho², Nanang \\ Fakhrudin $^{3 *}$, Puji Astuti ${ }^{3}$, Sudarsono ${ }^{3}$
}

\begin{abstract}
Background: The effects of tylophorine, a natural alkaloid found in Tylophora indica, administered as a single compound or in combination with doxorubicin on cell cycling and apoptosis were assessed in T47D breast cancer cells, selected as a model system for breast cancer. Methods: Cell cycle distribution and apoptosis were examined by flow cytometry. Caspase 3 and 9 expression was determined by immunocytochemistry. Result: We found that tylophorine did not significantly influence the cell cycle distribution of T47D cells. However, the alkaloid did prevent accumulation of cells in the G2/M phase. In addition, tylophorine increased the number of apoptotic cells. Expression of proapoptotic proteins (caspases 3 and 9 ) was up-regulated upon administration of tyloporine alone or in combination with doxorubicin. Conclusions: Tylophorine alone or in combination with doxorubicin induced apoptosis in T47D breast cancer cells through modulation of the cell cycle and affecting the expression of caspases 3 and 9.
\end{abstract}

Keywords: Tylophorine- cell cycle- apoptosis- caspase 3 and 9- T47D

Asian Pac J Cancer Prev, 19 (11), 3065-3069

\section{Introduction}

Cancer is a pathological condition characterize by abnormal, quick, and uncontrollable cell growing. Cancer cells grown infinitely and invade surrounding tissues (Nafrialdi and Sulistia, 2007). Based on global statistical data of cancer, breast cancer is the most deadly cancer in (Parkin et al., 2002).

Many efforts have been done in the treatment of breast cancer such as chemotherapy, radiotherapy, hormonal, until surgery. The most common attempt is chemotherapy because this method is the ultimate theraphy to treat cancer cells the metastasis stage (Hanahan, 2000). The most common chemotherapeutic agents widely used in the medication of breast cancer are doxorubicin, cisplatin and 5-fluorouracil. However; these chemotherapeutic agents have some limitations as they lead to new other problems such as cancer cell resistance and the presence of toxic effects on normal cells (Fimognari et al., 2006).

One attempt to overcome this problem is by utilizing natural chemotherapeutic agents, especially from plant-derivate compounds. One of the plant-derived compounds is thylophorin, this phenanthroindolizidine alkaloid was found in Tylophora indica (Saraswati et al., 2013) and also presents in other Ficus family including Ficus septica (Wu et al., 2003).
Tylophorine is reported to have anti-cancer activity by affecting the cell cycle profile of liver cancer cells (HepG2), gastric cancer cells (NUGC-3) and nasopharyngeal cancer cells (HONE-1) (Wu et al., 2009). It also, demonstrated cytotoxic effect on nasopharyngeal (HONE-1) and gastric (NUGC-3) cancer cells (Damu et al., 2005).; In this study we further investigated the anticancer effect of tylophorin on breast cancer cells T47D by evaluating the influence on apoptosis process.

\section{Materials and Methods}

Tylophorine was obtained from Toronto Research Chemical Inc (catalog number T898200). This compound was dissolved in DMSO (Dimethyl Sulfoxide), prepared into aliquots, and stored at $-20{ }^{\circ} \mathrm{C}$. Primary monoclonal antibodies for to antigen caspase 3 (catalog number 9662) and caspase 9 (catalog number 9502). Doxorubicin (Ebewe) was obtained from PT Ferron Par Pharmaceutical (Cikarang, Indonesia).

\section{Cell lines and culture conditions}

T47D (Human ductal breast epithelial tumor cell line) was obtained from Laboratory of Parasitology, Faculty of Medicine, Universitas Gadjah Mada Indonesia. The cells were cultured in DMEM (Dulbecco's Modified

${ }^{1}$ Postgraduate Program of Pharmaceutical Sciences, ${ }^{2}$ Department of Pharmacology and Clinical Pharmacy, ${ }^{3}$ Department of Pharmaceutical Biology, Faculty of Pharmacy, Universitas Gadjah Mada, Yogyakarta, Indonesia. *For Correspondence: nanangf@ugm.ac.id 
Eagle's Medium) (Gibco) with 10\% Fetal Bovine Serum (Gibco), 2\% Sodium bicarbonate (Gibco) and HEPES (4-2(2-hydroxyethyl)-1-piperazineethanesulfonic acid) (Invitrogen). The cell lines were maintained at $37^{\circ} \mathrm{C}$ in a humidified incubator containing $5 \% \mathrm{CO}_{2}$.

\section{Cell cycle analysis and Apoptotic assay}

Induction of apoptosis was performed by incubating the test substances within 24 hours into a 6-well plate with $5 \times 10^{5}$ cells/sinks. Observation was done with flow cytometry using Annexin $\mathrm{V}$ as a reagent. At the end of the incubation time, the medium was collected and the cell were harvested with trypsin $(200 \mu \mathrm{L} /$ well $)$. The cells suspension were centrifuged at 2,000 rpm for 5 minutes and the cells pellet was washed with the addition of PBS and centrifuged at 2,000 rpm for 5 minutes. The supernatant was removed and the cells pellet was collected for analysis. The cells pellet was used for the cell cycle assay and apoptosis assay. For the cell-cycle assay, the cells was resuspended in $25 \mu \mathrm{L}$ PI $(50 \mathrm{x})+1$ $\mu \mathrm{l}$ RNase $+0.5 \mu \mathrm{l}$ Triton-X + PBS ad $500 \mu \mathrm{l}$. Where as for the apoptosis assay the cells was resuspended in $600 \mu \mathrm{L}$ buffer, $12 \mu \mathrm{L}$ PI, and $12 \mu \mathrm{L}$ Annexin-V. The cell suspension was homogenized and incubated for 5 minutes at room temperature. The cells were then transferred to flowcyto-tube for analysis in a flowsitometer.

\section{Immunocytochemistry}

T47D cells were seeded at $5 \times 10^{5}$ cells/well on coverslips in 24-well plate until $80 \%$ confluent $(24 \mathrm{~h}$ incubation). The medium was then replaced by fresh medium containing tylophorine, doxorubicin or their combination. The cells was then incubated in a humidified incubator $\left(37^{\circ} \mathrm{C}\right.$ and $\left.5 \% \mathrm{CO}_{2}\right) \mathrm{O}_{2}$ for $24 \mathrm{~h}$. After incubation, the medium was discharded and the cells were washed with PBS and then fixed with cold methanol for $10 \mathrm{~min}$ at $-4^{\circ} \mathrm{C}$. Afterward, the cells were washed with PBS and blocked in hydrogen peroxide blocking solution for $10 \mathrm{~min}$ at room temperature. The cells were incubated with primary antibody of caspase 3 and 9 for $1 \mathrm{~h}$ at room temperature. The cells

were washed three times with PBS, then incubated with secondary antibody for $10 \mathrm{~min}$. After washing with PBS, the cells were incubated in 3,3 diaminobenzidine solution

for $10 \mathrm{~min}$ and then washed with aquadest. After this step, the cells were counterstained with Mayer-Haematoxylin for $3 \mathrm{~min}$. After incubation, the coverslips were taken and the stained cells were washed with aquadest, and then immersed with xylol and alcohol. The expression of caspase 3 and 9 proteins were observed using a light microscope (Nikon, Japan) and photographed using a digital camera (Canon, Japan). Positive and negative expressions of protein were represented by a dark brown and purple color in a the cells cytoplasm, respectively.

\section{Results}

In the previous study, we demonstrated that tylophorine and doxorubicin exerted cytotoxic effect in T47D cells with the IC50 of 113 and $0.13 \mu \mathrm{M}$. Respectively (Sundhani, 2015). Thus we used these IC50 values in this present study.

\section{Cell cycle modulation}

The amount of DNA contained in the cell is used to determine the distribution of cells including G0/G1, S and G2/M phases. Cell cycle profiles of T47D cells upon the treatment was analysed using flowcytometer and illustrated in (Figure 1). Most of the T47D cells accumulated in the G2-M phase indicating that. The treatment of tylophorine, and doxorubicin alone or combination can modulate the cell cycle and lead to the accumulation in certain phases. The cells cycle was shifted to G2-M after treatment with tylophorine $28.8 \mu \mathrm{M}$ and $56.5 \mu \mathrm{M}$ with the percentage of $29,72 \%$, and $29,83 \%$, respectively. After treatment with a doxorubicin the G2-M phase reached $46,43 \%$. Whereas the combination doxorubicin and tylophorine showed cell cycle arrest in G2-M phase as much as $28,06 \%$ and $30,71 \%$ for tylophorine $28.8 \mu \mathrm{M}$ and $56.5 \mu \mathrm{M}$ respectively

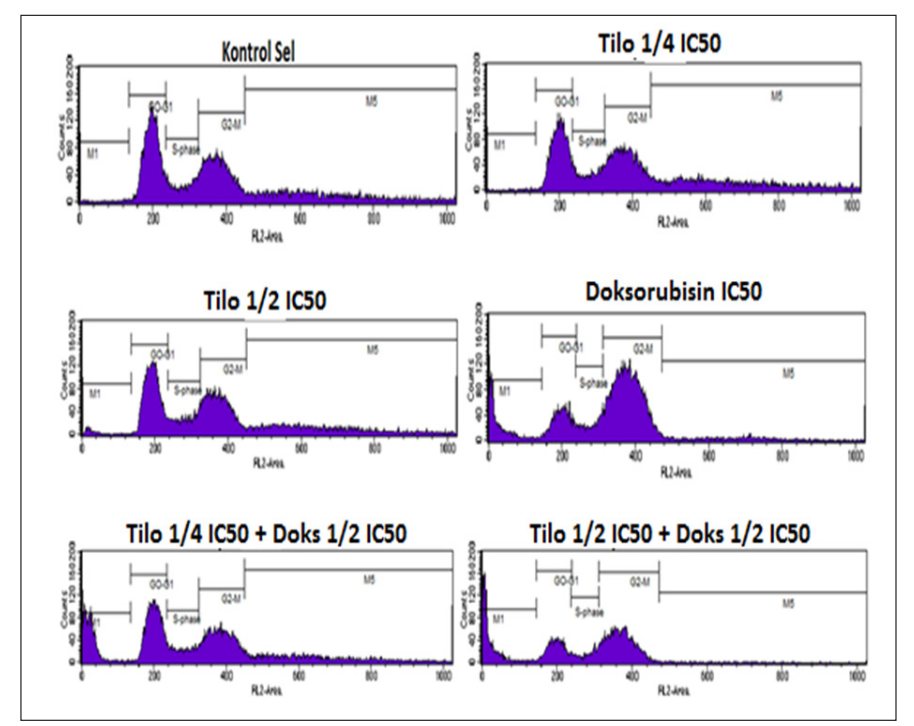

Figure 1. Detection of Cell Cycle Distribution Using Flowcytometry. 5 x 105 cells were seeded in 6-well plates and incubated for 24 hours in medium without or with treatment. Flowcytometric detection was done using PI reagent after treatment with tylophorine, doxorubicin, and their combination. 
Table 1. Cell Cycle Distribution of T47D Cells after Treatment

\begin{tabular}{lcccccc}
\hline Fase & Control & $\begin{array}{c}\text { Doxorubicin } \\
0.13 \mu \mathrm{M}\end{array}$ & $\begin{array}{c}\text { Tylophorine } \\
28.8 \mu \mathrm{M}\end{array}$ & $\begin{array}{c}\text { Tylophorine } \\
56.5 \mu \mathrm{M}\end{array}$ & $\begin{array}{c}\text { Tylophorine } \\
28.8 \mu \mathrm{M}+\text { Doxorubicin }\end{array}$ & $\begin{array}{c}\text { Tylophorine } \\
56.5 \mu \mathrm{M}+\text { Doxorubicin }\end{array}$ \\
\hline Sub G0 & 4.84 & 14.67 & 1.61 & 2.56 & 15.07 & 19.9 \\
G0-G1 & 29.07 & 19.82 & 27.91 & 29.84 & 28.49 & 25.52 \\
S & 13.29 & 10.27 & 10.88 & 10.27 & 10.8 & 13.78 \\
G2-M & 26.91 & 46.43 & 29.72 & 29.83 & 28.06 & 30.71 \\
\hline
\end{tabular}
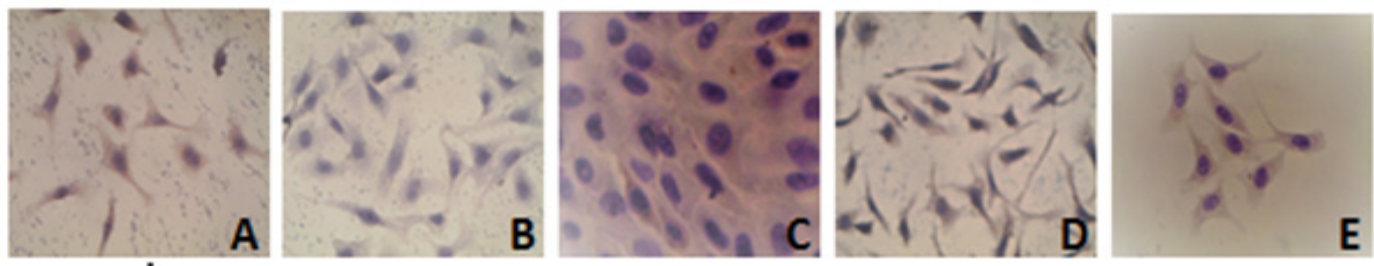

Figure 2. Expression of Caspase 3 on T47D Cells (400x). A, Control cells with caspase 3 antibodies; B, Control CELLS without caspase 3 antibodies; C, Tylophorine $113 \mu \mathrm{M}$; D, Doxorubicin $0.13 \mu \mathrm{M}$; E, Combination of $113 \mu \mathrm{M}$ and $0.13 \mu \mathrm{M}$. Expression of Caspase is characterized by the brown color of the cell cytoplasm.

Table 2. Percentage of Apoptotic T47D Cells

\begin{tabular}{lcccccc}
\hline Phase & Control (\%) & $\begin{array}{c}\text { Tylophorine } \\
28.8 \mu \mathrm{M}(\%)\end{array}$ & $\begin{array}{c}\text { Tylophorine } \\
56.5 \mu \mathrm{M}(\%)\end{array}$ & $\begin{array}{c}\text { Doxorubicin } \\
0.13 \mu \mathrm{M}(\%)\end{array}$ & $\begin{array}{c}\text { Tylophorine } \\
28.8 \mu \mathrm{M}+\text { Doxorubicin }(\%)\end{array}$ & $\begin{array}{c}\text { Tylophorine } \\
\text { Doxorubicin }(\%)\end{array}$ \\
\hline Apoptosis & 4.59 & 6.23 & 7.93 & 9.96 & 52.83 & 53.76 \\
Necrosis & 1.69 & 1.98 & 2.47 & 5.21 & 13.6 & 10.11 \\
\hline
\end{tabular}
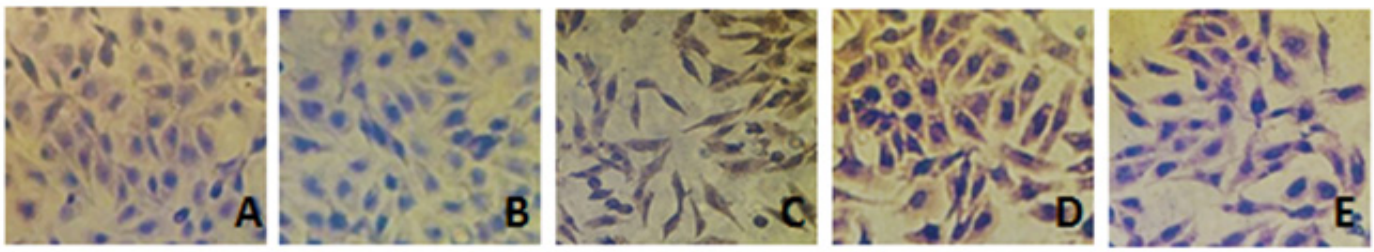

Figure 3. Expression of Caspase 9 on T47D Cells (400x). A, Control cells with caspase 9 antibodies; B, Control cells without caspase 9 antibodies; C, Tylophorine $113 \mu \mathrm{M}$; D, Doxorubicin $0.13 \mu \mathrm{M}$; E, Combination of $113 \mu \mathrm{M}$ and 0.13 $\mu \mathrm{M}$. Expression of Caspase is characterized by the brown color of the cell cytoplasm.

(Table 1).

\section{Induction of Apoptosis}

The percentage of apoptotic cells (early and late apoptosis) was also calculated by flowcytometer. Table 2 showed the result of the apoptosis assay. The percentage of apoptotic cells in the control group was lower than that of tylophorine, doxorubicin, and the combination thereof. This suggested that tylophorine at $28.8 \mu \mathrm{M}$ and $56.5 \mu \mathrm{M}$ was able to induce apoptosis in T47D cells $6.23 \%$ and $7.93 \%$ respectively.

\section{Expression of Caspase 3 and 9}

Evaluation of Caspase 3 and 9 was performed using immunocytochemical method. Positive expression of Caspase 3 and 9 are characterized by brown color of the cell cytoplasm. Observed under the microscope the cells without antibodies showed no brown color in the cytoplasm suggesting that. The expression of Caspase 3 and 9 proteins was negative (Figure.2B, 3B). Addition with antibodies was able to visualize Caspase 3 and 9 expressions indicated by brown cytoplasm. A single treatment of tylophorine or doxorubicin increased the expression of both Caspase 3 and 9 compared to control cells. The combination of tylophorine and doxorubicin was also increased the level expression of the protein compared to control cells.

\section{Discussion}

In this study, we reported the anti-cancer potential of tylophorine, a natural product derived from medicinal plants. This study is a part of the effort to develop a new anti-cancer agents either as an extract, fraction, single compound or combination of an active natural compound with an established drugs. To improve the pharmacological profile (Febriansah et al., 2014; Nugroho et al., 2014a; Sunarwidhi et al., 2014). Interestingly in line with the growing use of medical plants, the development of antihypertensive, anti-allergy, anti cancer and anti-diabetic drugs either as a single agent or combination is increasing (Harwoko et al., 2014; Nugroho et al., 2011a; Nugroho et al., 2011b; Nugroho et al., 2013b).

In this study, tylophorine a plant-derived alkaloid was Asian Pacific Journal of Cancer Prevention, Vol $19 \mathbf{3 0 6 7}$ 
evaluated for its apoptotic effect and its effect on cell cycle distribution in T47D breast cancer cells. Evaluation of cell cycle distribution and apoptosis were performed using flowcytometry, and caspase 3 and 9 protein expression was determined by immunocytochemical method. Tylophorine and doxorubicin as have been evaluated for its cytotoxic effect in our previous study. IC50 values of tylophorine and doxorubicin were 113 and $0.13 \mu \mathrm{M}$ respectively (Sundhani, 2015).

The treatment of tylophorine or doxorubicin, and a combination of both compounds in T47D cells exhibited accumulation of cells in the G2-M phase within 24-hour incubation period. The highest cells' accumulation in the G2-M phase occurred after the treatment with doxorubicin alone (Table 1). This indicating that the drug inhibits cell cycle and causes death in T47D cancer cells. This effect might occur-by linking the DNA, generating free radicals, interacting with cellular membranes and inhibiting topoisomerase II which play a role in DNA repair (Husein, 2007). Treatment of tylophorine induced a higher G1 phase accumulation in T47D cells than that of doxorubicin. Interestingly combination of tylophorine and doxorubicin shifted the cells' accumulation from G2-M to G1 phase. The facts suggest that tylophorine can improve doxorubicin effect by changing the inhibition of cell cycle phase G2/M to phase G1.

Treatment of the cells at with tylophorine was performed with two concentrations of $28.8 \mu \mathrm{M}$ and 56.5 $\mu \mathrm{M}$ exhibited apoptotic effect, even though these IC50 values were lower than this of doxorubicin, combination of tylophorine with doxorubicin was able to increase significantly the apoptotic effect in comparison to the single administration (Table 2). This indicated that there is a synergistic effect of tylophorine and doxorubicin when these compounds are combined. In the previous study, combination of doxorubicin of Ficus septica alkaloid fraction which might contain tylophorine enhanced cytotoxic effects of doxorubicin synergistically through inducing apoptosis by increasing the expression of cleaved Poly (ADP-ribose) polymerase (cPARP) (Nugroho, 2012).

The mechanism of apoptotic effect of the compounds used in this study is most likely influenced by the p53 gene. It is related to the characteristics of T47D cells that are p53 gene mutations that function in apoptotic events. In addition to the characteristics of T47D cells, it also expresses caspase 3 wildt ype, caspase 7 wild type, and ER/RR positive and sensitive to doxorubicin (Schafer et al., 2000). Phenantroindolisidine alkaloids including tylophorine have been shown to induce apoptosis by inhibiting extrinsic pathways by strengthening the action of TNF- $\alpha$ tumors that induce caspase 8 and poly (ADP-ribose) polymerase (PARP) cutting (Min et al., 2010). Tylophorine plays an important role in the indication of apoptosis of cancer cells through activation of caspase 3 and induces cytochrome c release which then will be bound by Apop-1 (apoptosis activating factor), which will form apoptosome. Apoptosom will activate caspase 9, and then the caspase 9 will activate caspase 3 that plays a role in apoptosis event (Ganguly et al., 2002). It indicates that tylophorine may cause apoptosis by increasing the expression of caspase 3 and 9 proteins in breast cancer cells.

Evaluation of caspase 3 and 9 expressions was done using immunocytochemical method. From the observations under the microscope treatment of the cells with tylophorine, doxorubicin or the combination increased the expressions of caspase 3 and 9 characterized by brown colour on the cytoplasm. This finding is in line with previous study by Vakkala et al., (1999) showing that the level of caspase 3 was increased by treatment of various chemotherapy agents. Caspase 3 is expressed in $90 \%$ of breast cancer cells. Caspase 3 expression is a signal transduction pathway in the apoptotic process at the downstream level. The initiation of caspase 9 activates caspase 3 which acts as the executor of a series of downstream cascades of proteolytic activity (apoptosis) in the form of digestion of protein structures in the cytoplasm and the destruction of DNA chromosomes (Rahmawati et al., 2010).

In conclusion, in this study we demonstrated that tylophorine alone or combination with doxorubicin induced apoptosis in T47D breast cancer cells through modulation of cell cycle and up regulating the expression of caspase 3 and 9 enzymes.

\section{Competing interest}

The authors declare that there is no conflict of interest related to this publication.

\section{Acknowledgements}

We thank to Directorate General of Higher Education of the Ministry of Research, Technology and Higher Education of the Republic of Indonesia through Hibah Berbasis Kompetensi Research Grant 2017 for Financial Support of the research.

\section{References}

Anonim (2005). Tanaman Obat Indonesaia: Awar-awar, IPTEKnet., BPPT dan Riset, Jakarta (diakses tanggal 21 september 2016).

Damu AG, Kuo P-C, Shi L-S, et al (2005). Phenanthroindolizidine Alkaloids from The Stems of Ficus septica. J Nat Prod, 68 , 1071-5.

Febriansah R, Dyaningtyas DP, Nurulita NA, Meiyanto E, Nugroho AE (2014). Hesperidin as a preventive resistance agent in $\mathrm{MCF}-7$ breast cancer cells line resistance to doxorubicin. Asian Pac J Trop Biomed, 4, 228-33.

Fimognari C, Nusse MN, Lenzi M, et al (2006). Sulforaphane increases the efficacy of doxorubicin in mouse fibroblasts characterized by p53 mutations. Mutat Res, 601, 92-101.

Hanahan D, Weinberg RA (2000). The hallmarks of cancer. Cell, 100, 57-70

Harwoko, Pramono S, Nugroho AE (2014). Triterpenoid-rich fraction of centella asiatica leaves and in vivo antihypertensive activity. Int Food Res $J, 21,149-54$.

Hussein MA (2007). Preclinical rationale, mechanisms of action, and clinical activity of anthracyclines in myeloma. Clin Lymphoma Myeloma Leuk, 4, 145-9.

Nafrialdi, dan Sulistia G (2007). Farmakologi dan Terapi Edisi 5: Antikanker, Departemen Farmakologi dan Terapeutik, Universitas Indonesia, Jakarta, pp 732-3.

Nugroho AE, Riyanto S, Sukari MA, Maeyama K (2011a). 
Effects of aegeline, a main alkaloid of Aegle marmelos Correa leaves, on the histamine release from mast cells. Pak J Pharm Sci, 24, 336-59.

Nugroho AE, Ikawati M, Hermawan A, Putri DDP, dan Meiyanto E (2011b). Cytotoxic effect of ethanolic extract fractions of Indonesia plant Ficus septica Burm. f. on human breast cancer T47D cell lines. Int J Phytomed, 3, 216-26.

Nugroho AE, Hermawan A, Putri DDP, et al (2012). Combinational effects of hexane insoluble fraction of Ficus septica Burm. f. and doxorubicin chemotherapy on T47D breast cancer cells. Asian Pac J Trop Biomed, In Press.

Nugroho AE, Hermawan A, Putri DDP, Novika A, dan Meiyanto E (2013). Combinational effects of hexane insoluble fraction of Ficus septica Burm. f. and doxorubicin chemotherapy on T47D breast cancer cells. Asian Pac J Trop Biomed, 3, 297-302.

Nugroho AE, Malik A, Pramono S (2013b). Total phenolic and flavonoid contents, and in vitro antihypertension activity of purified extract of Indonesian cashew leaves (Anacardium occidentale L.). Int Food Res J, 20, 299-305.

Nugroho AE, Kusumaramdani G, Widyaninggar A, Prasetyo Anggoro D, Pramono S (2014a). Antidiabetic effect of combinations of $n$-hexane insoluble fraction of ethanolic extract of Andrographis paniculata with other traditional medicines. Int Food Res J, 21, 785-9.

Parkin DM, Bray F, Ferlay J, et al (2002). Global cancer statics. CA Cancer J Clin, 55, 74-108.

Rahmawati DA, Hussana A (2010). In vitro study of the effect of anticancer protein isolated from Jarak Pagar (Jatropha curcas L) seeds. Inducing Apoptosis Through Caspase-3 Activation. Bagian Biokimia dan Farmakologi UNISSULA, 2, pp 21-2.

Shah MA, Schwartz GK (2001). Cell cycle-mediated drug resistence an emerging concept in cancer therapy. Clin Cancer Res, 7, 2168-81.

Saraswati S, Kanaujia P, Kumar S, Kumar R, Alhaider A (2013). Tylophorine, a phenanthraindolizidine alkaloid isolated from Tylophora indica exerts antiangiogenic and antitumor activity by targeting vascular endothelial growth factor receptor 2-mediated angiogenesis. Mol Cancer, 12, 82.

Schafer J, Soon Lee E, O’Regan R, Yao K, Jorand V (2000). Rapid development of tamoxifen-stimulted mutant p53 breast tumors (T47D) IN Athymic Mice. Clin Cancer Res, 6, 4373 .

Sunarwidhi AL, Sudarsono S, Nugroho AE (2014). Hypoglycemic effect of combination of Azadirachta indica A. Juss. and Gynura procumbens (Lour.) Merr. ethanolic extracts standardized by rutin and quercetin in alloxan-induced hyperglycemic rats. Adv Pharm Bull, 4, 613.

Sundhani E (2015). Efek sitotoksik, Proliferasi, dan Apoptosis Fraksi Alkaloid Daun Awar-awar (Ficus septica Burm. f.) Terhadap Sel Kanker Payudara T47D, Tesis, MSc, Fakultas Farmasi Universitas Gadjah Mada, Yogyakarta. Daun Awar-awar (Ficus septica Burm. f.) Terhadap Sel Kanker Payudara T47D, Tesis, MSc, Fakultas Farmasi Universitas Gadjah Mada, Yogyakarta.

Wu CM, Yang CW, Lee YZ, et al (2009). Tylophorine arrests carcinoma cells at G1 phase by downregulating cyclin A2 expression. Biochem Biophys Res Commun, 386, 140-5.

Wu PL, Rao KV, Su CH, et al (2003). Phenantroindolizidine alkaloids and their cytotoxicity from the Leaves of Ficus septica. ChemInform, 34, DOI: 10.1002/chin.200313190.

\section{(ब) $(\mathbb{8}$}

This work is licensed under a Creative Commons AttributionNon Commercial 4.0 International License. 